\title{
SILVER-HAIRED BATS ASSOCIATED WITH ABANDONED MINES IN COLORADO PROVIDE INSIGHTS INTO WINTER HABITAT AND ROOST USE
}

\author{
Lea’ R. Bonewell ${ }^{1}$, Mark A. Hayes ${ }^{2}$, Nancy LaMantia-Olson ${ }^{3}$, Elijah Wostl ${ }^{4}$, and Kirk W. Navo ${ }^{5}$
}

\begin{abstract}
Aвstract--Herein we present the first published records $(N=5)$ of silver-haired bats (Lasionycteris noctivagans) roosting in abandoned mines in Colorado during winter. The records are based on internal surveys of abandoned mines during the winter period from 2004 to 2008 . These noteworthy records provide insights into the winter roosting ecology and habitat use of this species in southwestern Colorado.
\end{abstract}

Resumen.-Presentamos aquí los primeros registros publicados $(N=5)$ de murciélagos de pelo plateado (Lasionycteris noctivagans) que se refugian, durante el invierno, en minas abandonadas de Colorado. Los registros están basados en inspecciones internas de tales minas, durante los períodos invernales del 2004 al 2008. Estos notables registros dan una idea sobre la ecología de refugio en el invierno y sobre el uso del hábitat de esta especie en el suroeste de Colorado.

The effective conservation of migratory animals requires knowledge of habitat use across seasons and ecoregions (Webster et al. 2002). Because bats in western North America are small, cryptic, and nocturnal, less is known about seasonal habitat use of migratory bat species than of more conspicuous taxa such as songbirds and waterfowl (Cryan 2003, Fleming and Elby 2003, Hayes et al. 2015). Conservation biologists, wildlife managers, and researchers have emphasized the need to improve our understanding of the roosting ecology of bats of conservation concern in the Southern Rocky Mountain region and elsewhere in the Rocky Mountain West; such information helps target conservation and management efforts and reduce human disturbance at key roosting resources (Adams 2003, Ellison et al. 2003, O'Shea et al. 2003, 2011, Hayes et al. 2011, Hayes and Adams 2015). For example, the Colorado Bat Conservation Plan (Ellison et al. 2003) has emphasized the need for more information on the seasonal roosting preferences of species of conservation concern.

In an effort to document and protect abandoned mines used as roosting locations by bat species of conservation concern, Colorado Parks and Wildlife (formerly known as Colorado Division of Wildlife) and the agency's Bats/ Inactive Mines Project (BIMP) conducted bat surveys throughout Colorado for over 2 decades, beginning in 1991 (Navo et al. 1991, Navo and Krabacher 2005, Hayes 2012). During January, February, and March 1999-2009, BIMP biologists focused winter survey efforts inside abandoned mines throughout southwestern Colorado (Navo 2001, Hayes et al. 2011). Biologists surveyed mines selected for reclamation efforts by the Colorado Division of Reclamation, Mining, and Safety, the U.S. Bureau of Land Management, and the U.S. Forest Service, all in collaboration with private landowners. When bats were observed inside abandoned mines, biologists recorded the following information: the species observed (when possible from visual inspection; bats were not handled or intentionally disturbed), the number of bats observed, whether bats were roosting singly or in groups, the elevation of the mine entrance, the temperature of the rock substrate near bats (e.g., infrared thermometer model Raynger ST2, Raytek Corporation, Santa Cruz, CA; air temperature near bats and body temperature of individual bats were not measured), the estimated depth of the mine, and the number of openings to the surface that could be identified.

The silver-haired bat (Lasionycteris noctivagans) is a species of conservation concern due in part to recent observations of dead individuals of this species found underneath wind turbines throughout North America

\footnotetext{
${ }^{1}$ United States Geological Survey, Fort Collins, CO 80526

2Corresponding author. Cherokee Nation Technologies, United States Geological Survey, Fort Collins, CO 80526. E-mail: hayes.a.mark@gmail.com ${ }^{3}$ Littleton, CO 80214

${ }^{4}$ University of Texas at Arlington, Arlington, TX 76019

${ }^{5}$ Head First Biological, Loveland, CO 80538.
} 
(Arnett and Baerwald 2013, Arnett et al. 2016). The silver-haired bat is known to roost in trees (Barbour and Davis 1969, Kunz 1982, Barclay et al. 1988, Campbell et al. 1996, Mattson et al. 1996, Betts 1998), rock crevices (Barbour and Davis 1969, Kunz 1982), caves (Frum 1953, Beer 1956, Kunz 1982), mines (e.g., in eastern North America; Pearson 1962, Kunz 1982), buildings (Barbour and Davis 1969, Gosling 1977, Izor 1979, Kunz 1982), and other human-made structures (Barbour and Davis 1969, Kunz 1982). Although this species has been documented hibernating in a wide variety of substrates and structures, little is known about roost use by this species in Colorado (Armstrong et al. 2011) and elsewhere in the Southern Rocky Mountains (Adams 2003). It also remains unclear where this species hibernates in large parts of western North America (Cryan 2003). This species is known to migrate long distances between summer and winter areas (Cryan 2003), potentially complicating our understanding of habitat and roost use. A silver-haired bat was recently documented in Washington State carrying the fungal species Pseudogymnoascus destructans (NWHC 2016), which is considered the causative agent of bat white-nose syndrome; this observation highlights the need to better understand the winter roosting habits of this species in western North America.

On 5 occasions from 2004 to 2008 , during fieldwork by biologists with the Colorado Bats/Inactive Mines Project, silver-haired bats were found that were associated with abandoned mines in southwestern Colorado.

(1) On 11 February 2004, during a daytime internal survey of an abandoned mine, 2 torpid silver-haired bats were found roosting in the mine. The mine was located on Joe Davis Hill (San Miguel County, $2060 \mathrm{~m}$ ) and was a complex feature that was at least $150 \mathrm{~m}$ deep and had 3 openings to the surface, all with south- to southwest-facing aspects. The mine was situated toward the top of Dolores Canyon overlooking the Dolores River, which was approximately $850 \mathrm{~m}$ from the mine. The bats were observed about $45 \mathrm{~m}$ and $60 \mathrm{~m}$ from the nearest opening to the surface, respectively, both roosting in crevices in the ceiling. The respective temperatures of the rock substrate next to the bats were $7.9^{\circ} \mathrm{C}$ and $0.4^{\circ} \mathrm{C}$.

(2) On 12 February 2004, during a daytime internal survey, another torpid silver-haired bat was found roosting in a mine, also on Joe Davis Hill (San Miguel County, 2090 m). This mine was an adit (a horizontal feature with an opening to the surface) that was at least $60 \mathrm{~m}$ deep with a southeast-facing portal. The mine was also situated toward the top of the Dolores Canyon overlooking the Dolores River, which was about $925 \mathrm{~m}$ from the portal. The bat was found about $18 \mathrm{~m}$ inside the mine, roosting in a crevice in the ceiling. The temperature of the rock substrate next to the bat was $6.6{ }^{\circ} \mathrm{C}$. This portion of Joe Davis Hill and the Dolores Canyon is surrounded by benchlands and mesas.

(3) On 18 January 2005, during a daytime internal survey, a torpid silver-haired bat was found roosting in an abandoned mine in a canyon on the east side of Hieroglyphic Mesa (Montrose County, 1750 m elevation), approximately $2.7 \mathrm{~km}$ from the San Miguel River. This mine was an adit complex that was about $75 \mathrm{~m}$ deep with 3 openings, all of which had northwest-facing aspects. The bat was found about $30 \mathrm{~m}$ inside the mine, roosting in a ceiling crevice. The temperature of the rock substrate next to the bat was $9.2{ }^{\circ} \mathrm{C}$.

(4) On 16 February 2008, during a daytime internal survey of an abandoned mine, a torpid silver-haired bat was found roosting in a shallow adit. The mine was located on Davis Mesa (Montrose County, $1860 \mathrm{~m}$ ). The exact location of this mine and the approximate location of the bat inside the mine are not known.

(5) In addition to these winter records, on 8 June 2005, between 21:30 and 00:00, a nonbreeding adult male silver-haired bat was captured in a harp trap (Kunz et al. 2009) set at a mine in Hieroglyphic Canyon (Montrose County, $1680 \mathrm{~m}$ ). It is unknown whether the bat was entering or exiting the mine. This mine was an adit that was at least $300 \mathrm{~m}$ deep with one portal, with a northwest aspect and about $1.5 \mathrm{~km}$ from the San Miguel River. This portion of Hieroglyphic Mesa consists of a mesa bisected by canyons.

Vegetation near all of these mines generally consisted of sparse piñon-juniper woodland (Pinus edulis and Sabina osteosperma) that included Gambel oak (Quercus gambelii) and sagebrush (Serphidium tridentatum). Riparian species along the San Miguel River and Dolores River included boxelder (Acer negundo), tamarisk (Tamarix chinensis), shrub willow (Salix spp.), and cottonwood (Populus spp.). 


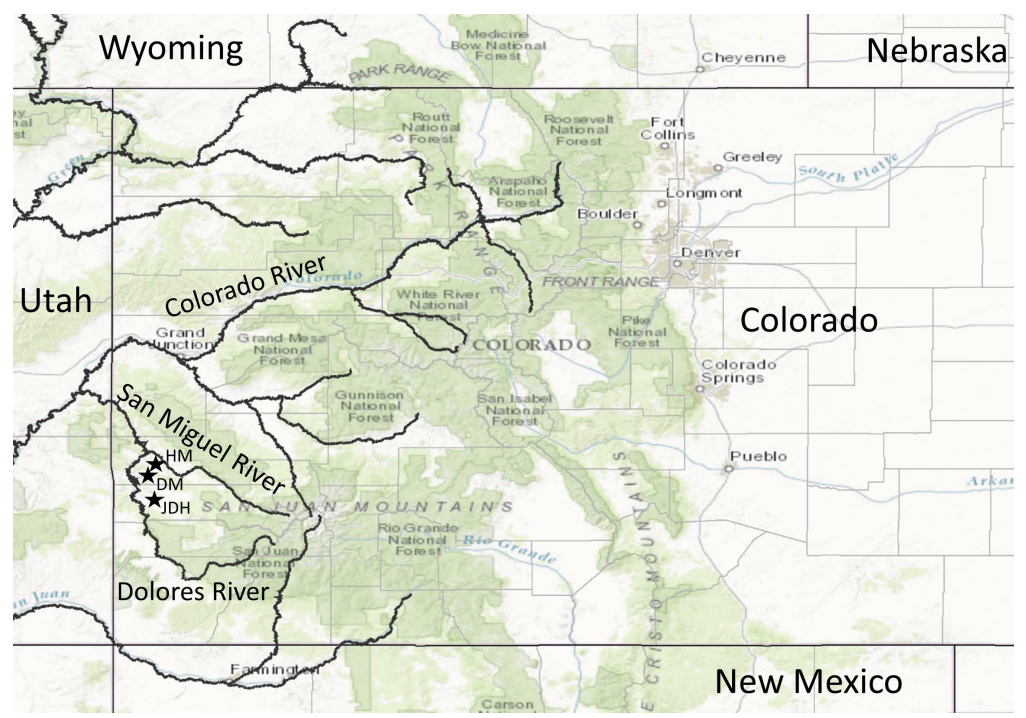

Fig. 1. Locations of silver-haired bats (Lasionycteris noctivagans) associated with abandoned mines in Colorado. The 3 black stars indicate the approximate locations of silver-haired bats associated with abandoned mines. DM indicates Davis Mesa, HM indicates Hieroglyphic Mesa (this is approximately the same location as the silver-haired bat observed in a mine near Uravan), and JDH indicates Joe Davis Hill.

In addition to the occurrences already mentioned, on 14 January 2013 a silver-haired bat was observed roosting in an abandoned mine near Uravan (Montrose County; personal communication, D. Neubaum). The approximate locations of all the mines mentioned are shown in Fig. 1.

The majority of winter occurrence records for silver-haired bats in North America have been from the eastern part of the continent, with some records from the Southwest and the Pacific Northwest (Cryan 2003). The 5 winter observations of silver-haired bats described here represent the first published records of this species using abandoned mines in Colorado; we are not aware of other observations of this species using abandoned mines in the Southern Rocky Mountains and Four Corners region, though this species has been captured at caves during the summer period in Colorado (Seimers 2002). Torpid silver-haired bats were found during winter inside abandoned mines that were both simple and complex in structure and that tended to be relatively close to rivers $(<3 \mathrm{~km})$. All torpid bats were found roosting singly in the ceilings of abandoned mines and inside crevices that were 18-60 $\mathrm{m}$ from the nearest entrance to the mine. The rock substrate adjacent to bats was between $0.4{ }^{\circ} \mathrm{C}$ and $9.2{ }^{\circ} \mathrm{C}$. Together, these winter and summer observations suggest that silver-haired bats opportunistically use abandoned mines as refugia during winter and summer, and that this species may regularly hibernate in southwestern Colorado. These winter observations comport with winter roosting behavior of silver-haired bats observed elsewhere in North America where this species has been regularly observed hibernating in caves and mines (Cowan 1933, Frum 1953, Beer 1956, Pearson 1962, Barbour and Davis 1969, Gosling 1977, Kunz 1982, Nagorsen et al. 1993, Cryan 2003) and add to our understanding of the winter roosting ecology and habitat use of this species in western North America. We conclude that it is likely that during winter silver-haired bats occasionally utilize abandoned mines that are regularly used by other western species, such as Townsend's big-eared bat (Corynorhinus townsendii), cave and mine dwelling Myotis spp., and other species, such as big brown bat (Eptesicus fuscus), canyon bat (Parastrellus hesperus), and Mexican free-tailed bat (Tadarida brasiliensis) (Navo et al. 1991, Adams 2003, Navo and Krabacher 2005, Hayes et al. 2011, Hayes and Adams 2015).

We thank Colorado Parks and Wildlife and the Colorado offices of the Bureau of Land 
Management for facilitating this work. We also thank the volunteers of the Colorado Bats/ Inactive Mines Project (BIMP) for their longstanding dedication to the conservation of bats in Colorado.

\section{Literature Cited}

ADAms, R.A. 2003. Bats of the Rocky Mountain West: natural history, ecology, and conservation. University Press of Colorado, Boulder, CO.

Armstrong, D.M., C.A. Meaney, and J.P. Fitzgerald. 2011. Mammals of Colorado. Denver Museum of Natural History and University Press of Colorado, Niwot, CO.

ARNETT, E.B., AND E.F. BAERWALD. 2013. Impacts of wind development on bats: implications for conservation. Pages 435-456 in R.A. Adams and S.C. Pedersen, editors, Bat evolution, ecology, and conservation. Springer, New York, NY.

Arnett, E.B., E.F. Baerwald, F. Mathews, L. Rodrigues, A. Rodríguez-Durán, J. Rydell, R. VilllegasPatraca, and C.C. VOIGT. 2016. Impacts of wind development on bats: a global perspective. Pages 295-323 in C.C. Voigt and T. Kingston, editors, Bats in the Anthropocene: conservation of bats in a changing world. Springer, Lubbock, TX.

Barbour, R.W., and W.H. Davis. 1969. Bats of America. University of Kentucky, Lexington, KY.

Barclay, R.M.R., P.A. Faure, and D.R. Farr. 1988. Roosting behavior and roost selection by migrating silver-haired bats (Lasionycteris noctivagans). Journal of Mammalogy 69:821-825.

BEER, J.R. 1956. A record of a silver-haired bat in a cave. Journal of Mammalogy 37:282.

BETTS, B.J. 1998. Roosts used by maternity colonies of silver-haired bats in northeastern Oregon. Journal of Mammalogy 79:643-650.

Campbell, L.A., J.G. Hallett, and M.A. O’Connell. 1996. Conservation of bats in managed forests: use of roosts by Lasionycteris noctivagans. Journal of Mammalogy 77:976-984.

Cowan, I.M. 1933. Some notes on the hibernation of Lasionycteris noctivagans. Canadian Field-Naturalist 47:74-75.

CRYan, P.M. 2003. Seasonal distribution of migratory tree bats (Lasiurus and Lasionycteris) in North America. Journal of Mammalogy 84:579-593.

Ellison, L.E., M.B. Wunder, C.A. Jones, C. Mosch, K.W. Navo, K. Peckham, J.E. Burghardt, J. Annear, R. West, J. Seimers, et AL. 2003. Colorado Bat Conservation Plan. Colorado Committee of the Western Bat Working Group.

Fleming, T.H., AND P. ELbY. 2003. Ecology of bat migration. Pages 156-208 in T.H. Kunz and B. Fenton, editors, Bat ecology. University of Chicago Press, Chicago, IL.

Frum, W.G. 1953. Silver-haired bat, Lasionycteris noctivagans, in West Virginia. Journal of Mammalogy 34:499-500.

GosLing, N.M. 1977. Winter record of the silver-haired bat, Lasionycteris noctivagans Le Conte, in Michigan. Journal of Mammalogy 58:657.

Hayes, M.A. 2012. Bats, mines, and citizen science in the Rockies: volunteers make a difference in Colorado. Bats 30:10-11.
Hayes, M.A., And R.A. Adams. 2015. Maternity roost selection by fringed myotis in Colorado. Western North American Naturalist 75:460-473.

Hayes, M.A., P.M. Cryan, and M.B. Wunder. 2015. Seasonally-dynamic presence-only species distribution models for a cryptic migratory bat impacted by wind energy development. PLOS ONE 10(7): e0132599.

Hayes, M.A., R.A. Schorr, and K.W. Navo. 2011. Hibernacula selection by Townsend's big-eared bat (Corynorhinus townsendii) in southwestern Colorado. Journal of Wildlife Management 75:137-143.

Izor, R.J. 1979. Winter range of the silver-haired bat. Journal of Mammalogy 60:641-643.

KunZ, T.H. 1982. Lasionycteris noctivagans. Mammalian Species 172:1-5.

Kunz, T.H., R. Hodgkins, And C.D. Weise. 2009. Methods of capturing and handling bats. Pages 3-35 in T.H. Kunz and S. Parsons, editors, Ecological and behavioral methods for the study of bats. Johns Hopkins University Press, Baltimore, MD.

Mattson, T.A., S.W. Buskirk, and N.L. Stanton. 1996. Roost sites of the silver-haired bat (Lasionycteris noctivagans) in the Black Hills, South Dakota. Great Basin Naturalist 56:247-253.

Nagorsen, D.W., A.A. Bryant, D. Kerridge, G. Roberts, A. Roberts, and M.J. Sarell. 1993. Winter bat records for British Columbia. Northwestern Naturalist 74:61-66.

[NWHC] National Wildlife Health Center. 2016. Wildlife Health Bulletin 2016-05: White-nose syndrome updates for the 2015/2016 surveillance season. www.nwhc.usgs.gov/publications/wildlife_health _bulletins/WHB_2016-05_WNS_updates.pdf

Navo, K.W. 2001. The survey and evaluation of abandoned mines for bat roosts in the West: guidelines for natural resource managers. Proceedings of the Denver Museum of Nature \& Science 4(2):1-12.

Navo, K.W., C.L. KnapP, AND J. Sheppard. 1991. Colorado’s Bats/Inactive Mines Project. Bat Research News 32:81.

Navo, K.W., AND P. Krabacher. 2005. The use of gates at abandoned mines in Colorado. Bat Research News 46:1-8.

O'Shea, T.J., M.A. Bogan, and L.E. Ellison. 2003. Monitoring trends in bat populations of the United States and territories: status of the science and recommendations for the future. Wildlife Society Bulletin 31:16-29.

O’Shea, T.J., P.M. Cryan, E.A. Snider, E.W. Valdez, L.E. Ellison, and D.J. Neubaum. 2011. Bats of Mesa Verde National Park, Colorado: composition, reproduction, and roosting habits. Monographs of the Western North American Naturalist 5:1-19.

Pearson, E.W. 1962. Bats hibernating in silica mines in southern Illinois. Journal of Mammalogy 43:27-33.

Seimers, J.L. 2002. A survey of Colorado's caves for bats. Colorado Natural Heritage Program, Fort Collins, CO.

Webster, S.M., P.P. Marra, S.M. Haig, S. Bensch, and R.T. HoLmes. 2002. Links between worlds: unraveling migratory connectivity. Trends in Ecology and Evolution 17:76-83.

Received 7 September 2016 Accepted 31 July 2017

Published online 28 September 2017 